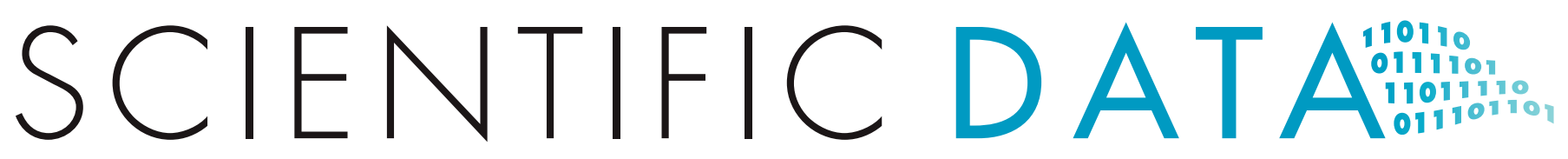

\title{
Corrigendum: Transcriptome characterisation and simple sequence repeat marker discovery in the seagrass Posidonia oceanica
}

D. D’Esposito, L. Orrù, E. Dattolo, L. Bernardo, A. Lamontanara, L. Orsini, I.A. Serra, S. Mazzuca \& G. Procaccini

Scientific Data 3:160115 doi: 10.1038/sdata.2016.115 (2016); Published 20 December 2016; Updated 14 March 2017

The original version of this Data Descriptor contained a typographical error in the spelling of the author A. Lamontanara, which was incorrectly given as A. Lamontara. This has now been corrected in the PDF and HTML versions of the Data Descriptor.

(c) This work is licensed under a Creative Commons Attribution 4.0 International License. The
images or other third party material in this article are included in the article's Creative Commons license, unless indicated otherwise in the credit line; if the material is not included under the Creative Commons license, users will need to obtain permission from the license holder to reproduce the material. To view a copy of this license, visit http://creativecommons.org/licenses/by/4.0

() The Author(s) 2017 